九州大学学術情報リポジトリ

Kyushu University Institutional Repository

The impacts of sport hunting on the livelihoods of local people : A case study of Bénoué National Park, Cameroon

Yasuda, Akito

Kyoto University

http://hdl. hand le. net/2324/26542

出版情報: Society \& Natural Resources : An International Journal. 24 (8), pp.860-869, 2011-08. Taylor \& Francis

バージョン:

権利関係: (C) 2011 Taylor \& Francis Group, LLC 
Yasuda, A.

\title{
The impacts of sport hunting on the livelihoods of local people: A case study of Bénoué National Park, Cameroon
}

\author{
Akito Yasuda \\ Graduate School of Asian and African Area Studies \\ Kyoto University, Kyoto, Japan \\ 46 Shimoadachi-cho, Yoshida, Sakyo-ku, Kyoto, 606-8501, JAPAN \\ E-mail: yasudakeyaki@gmail.com
}

\begin{abstract}
:
This paper highlights the social impacts of sport hunting on the livelihoods of local people with a case study around Bénoué National Park, Northern Cameroon. Sport hunting is a way for local people to receive economic benefits from wildlife resources concerning community conservation. However, social impacts on local people, such as displacement and restriction of access to natural resources, have not been considered in the argument. Nineteen months of fieldwork, mainly based on interviews and observations in one village, showed that sport hunting in Northern Cameroon generated tax revenues about US $\$ 1.2$ million in 2008 and also provided profit sharing and employment opportunities in the communities. However, the proportion is less than other African countries such as in Tanzania, and at the same time, both employment opportunities and profit sharing were inequitable in the community. Simultaneously, locals' right to use natural resources, especially hunting, even for their livelihood, was regulated.
\end{abstract}

Keywords: Bénoué National Park, Cameroon, community conservation, protected areas, safari, 
social impact on local people, sport hunting, sustainability

\section{Acknowledgments}

This study was funded by a Grant-in-Aid for JSPS Fellows, a Sasagawa Scientific Research Grant from The Japan Science Society, the Shibusawa Fund for Ethnological studies, and the Support Program for Improving Graduate School Education of ASAFAS. My appreciation goes to Drs. M. Ichikawa, S. Kitoh, G. Yamakoshi, and D. Kimura. I also sincerely thank all villagers, the hunting zone operators, MINFOF, MINRESI and WWF-Cameroon for their unreserved collaboration and hospitality.

\section{Introduction}

Sport hunting, also known as trophy hunting, game hunting, and safari hunting, is the hunting of wildlife for sport or recreation. Today, sport hunting plays an important role in the tourism industry in Africa (Lewis and Alpert 1997; Chardonnet et al. 2002; Lindsey et al. 2007). The number of countries in sub-Saharan Africa authorizing sport hunting increased from 20 in 1991 to 25 in 2003, and the number of visiting hunters increased from 8,000 in 1990 to 12,000 in 2003 (Roulet 2004). Lindsey et al. (2007) estimated the scale of sport hunting in Africa by combining data from available references published between 1999 and 2005; the result showed that at least 18,500 hunters visited sub-Saharan Africa, generating gross revenues of at least US\$201 million per year.

Sport hunting also plays an important role in community conservation, which aims to involve local people as the main leaders in conservation and resource management activities, sharing tourism revenue and providing employment opportunities generated from conservation and tourism (Adams and Hulme 2001; Chardonnet et al. 2002). Sport hunting is a way in which local people can receive economic benefits from wildlife resources and strongly support community 
Yasuda, A.

conservation in some countries (Baker 1997). For example, in the CAMPFIRE (Communal Areas Management Programme for Indigenous Resources) project in Zimbabwe between 1989 and $2001,89 \%$ of the total project revenue came from sport hunting, and about half of the total project revenue was disbursed to communities (Frost and Bond 2008). This model of using sport hunting to conserve wildlife and to generate income for local communities is now being utilized by other nations such as the Central African Republic, Burkina Faso, and Ivory Coast (Wilkie and Carpenter 1999; Lindsey et al. 2007).

The importance of social impacts from protected areas and tourism activity on local peoples has received increasingly attention from researchers (e.g. Fairhead and Leach 2000; Chapin 2004). Not only the displacement of local people from protected areas, but also the restriction of their access to resources has been regarded as problematic (Cernea 2006). Tourism has conventionally been tolerated in protected areas even where local resource user have been excluded (Adams and Hutton 2007).

This paper, using a case study from Bénoué National Park in Cameroon (Figure 1) has two main aims. First, I evaluate statistics for sport hunting in Northern Cameroon. Second, I analyze the social and economic impacts of sport hunting on local people with the results from long-term fieldwork. 


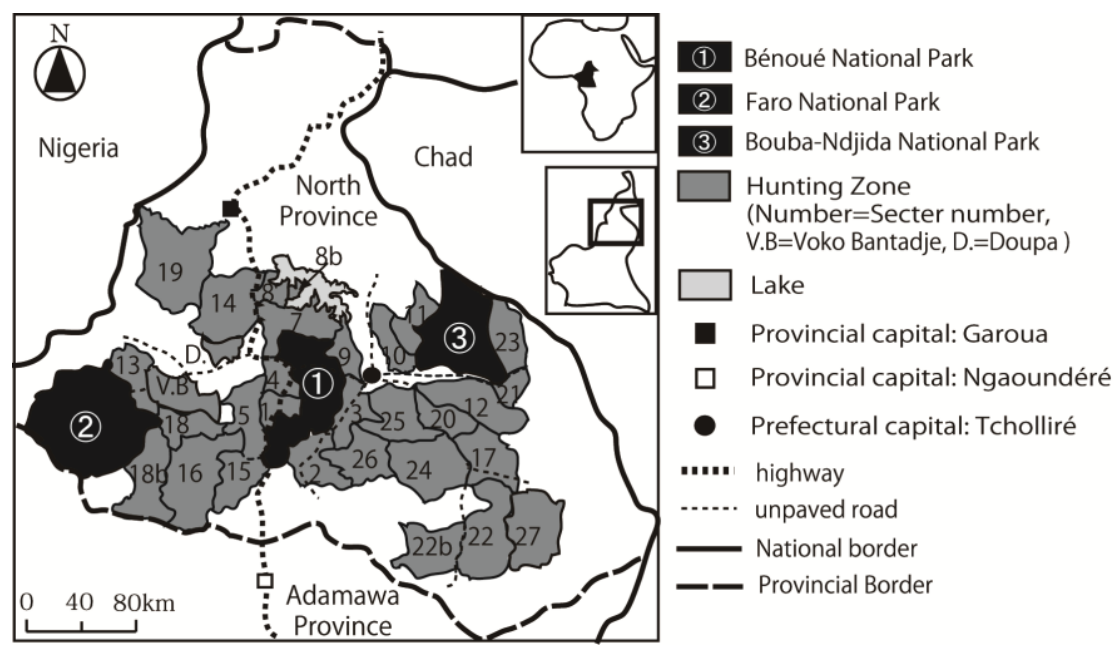

Figure 1. National parks and hunting zones in the North province, Cameroon. Adapted from WWF $(2007,9)$.

\section{Study Site and Research Methods}

Although sport hunting occurs on a smaller scale in Central and West Africa than in Southern and East Africa (Lindsey et al. 2007), Cameroon is one of the most popular countries for sport hunting in Central and West Africa (Roulet 2004). In Cameroon, sport hunting has historically occurred in the hunting zones around Bénoué National Park in the North province.

Bénoué National Park is covered by Sudan savanna (MINEF 2002). Elephant, lion, and Darby's eland (Taurotragus derbianus), the biggest antelope in Africa, live here. Annual rainfall is about 1000 to $1400 \mathrm{~mm}$, and the area has rainy (May-October) and dry (November-April) seasons.

I conducted field research in one village (not named, to protect local villagers), located in a hunting zone located on the east side of Bénoué National Park (see Figure 1) over 19 months between 2005 and 2009 .

The survey was based on social anthropological approaches (Chambers 1994) using participant observations and interviews, with the aim of identifying and ascertaining livelihoods and the impacts of the sport hunting conducted around the village. In 2007, the village had 287 
inhabitants and 25 households; $93 \%$ of the villagers were an agricultural people, called Dii (or Duru). Most of the villagers speak three languages: Dii, Fula and French. Interviews were conducted in French, but for the aged who did not speak French, I used a translator.

I also conducted a diet survey of five households selected at random to specify the frequency of meat in their diets. The five participants who were literate in each household wrote down what they ate at every meal from November 2004 to January 2005. When more than two kinds of meats were eaten at one meal, I counted it as one meat-eating episode.

In addition, I interviewed the officers of relevant ministries (MINEF; the Ministry of Environment and Forestry, and MINFOF; the Ministry of Forestry and Wildlife) and four hunting operators who operated the hunting zone around the village to obtain their opinions about the social impact of sport hunting on local peoples.

To understand the extent of sport hunting, I collected documents and reports issued by the ministries and nongovernmental organizations in the provincial capital, Garoua, and the national capital, Yaounde.

\section{Results}

\section{Present Status of Sport Hunting in Northern Cameroon}

The North province of Cameroon contains three national parks and 31 hunting zones (see Figure 1). In the national parks, all human activities are prohibited, except for photographic safari and scientific research. Sport hunting takes place in hunting zones outside the parks; the hunter must obtain a license from the government and pay hunting taxes. Local people can also reside in hunting zones.

Animals in Cameroon are classified as A, B, and C in accordance with Section 78 of Law 
No.94-1 of 20 January 1994 to Lay Down Forestry, Wildlife and Fisheries Regulation, hereafter "the Law." Class A species, such as leopard, giraffe, and cheetah, are completely protected and may not be killed; class B and C species, which are categorized into group 1, 2, and 3 for quotas, may be hunted with a permit. Sport hunters can hunt animals from classes B and C, but only within set quotas. For example, a sport hunter who has a license for big game can hunt two animals from class B group 1, i.e. elephant, Derby's eland, bongo (Tragelaphus euryceros), roan antelope (Hippotragus equines), African Buffalo (Syncerus caffer), hippopotamus (Hippopotamus amphibious), and topi (Damaliscus lunatus) and four animals from group 2, which includes waterbuck (Kobus ellipsiprymnus), hartebeest (Alcelaphus buselaphus), kob (Kobus kob), and so on. The game hunted by sport hunters belongs to the hunter in accordance with Section 96 of the Law, and most is consumed in hunting camps by hunters and employees.

Each hunting zone is leased by the government for US $\$ 0.15 /$ ha/year to a resident hunting operator, most of whom are from Europe. The 21 lessees were comprised of French $(52 \%, 11)$, Spanish $(14 \%, 3)$, Italian $(10 \%, 2)$, Greek, Danish, German, Turkish, and Norwegian (each 5\%, 1) operators. The leases must be renewed every five years, and lessees obtain the right to use natural resources in their zones, construct or convert hunting camps, and invite hunters. Between 1983 and 1997, 2,424 hunters visited Northern Cameroon (WWF 2000); 90\% (2,182) were foreigners from 34 nations, notably from France (52\%). Since the early 2000s, the total annual number of hunting licenses issued by the Ministry has stayed at around 250 (Figure 2a). 
Yasuda, A.

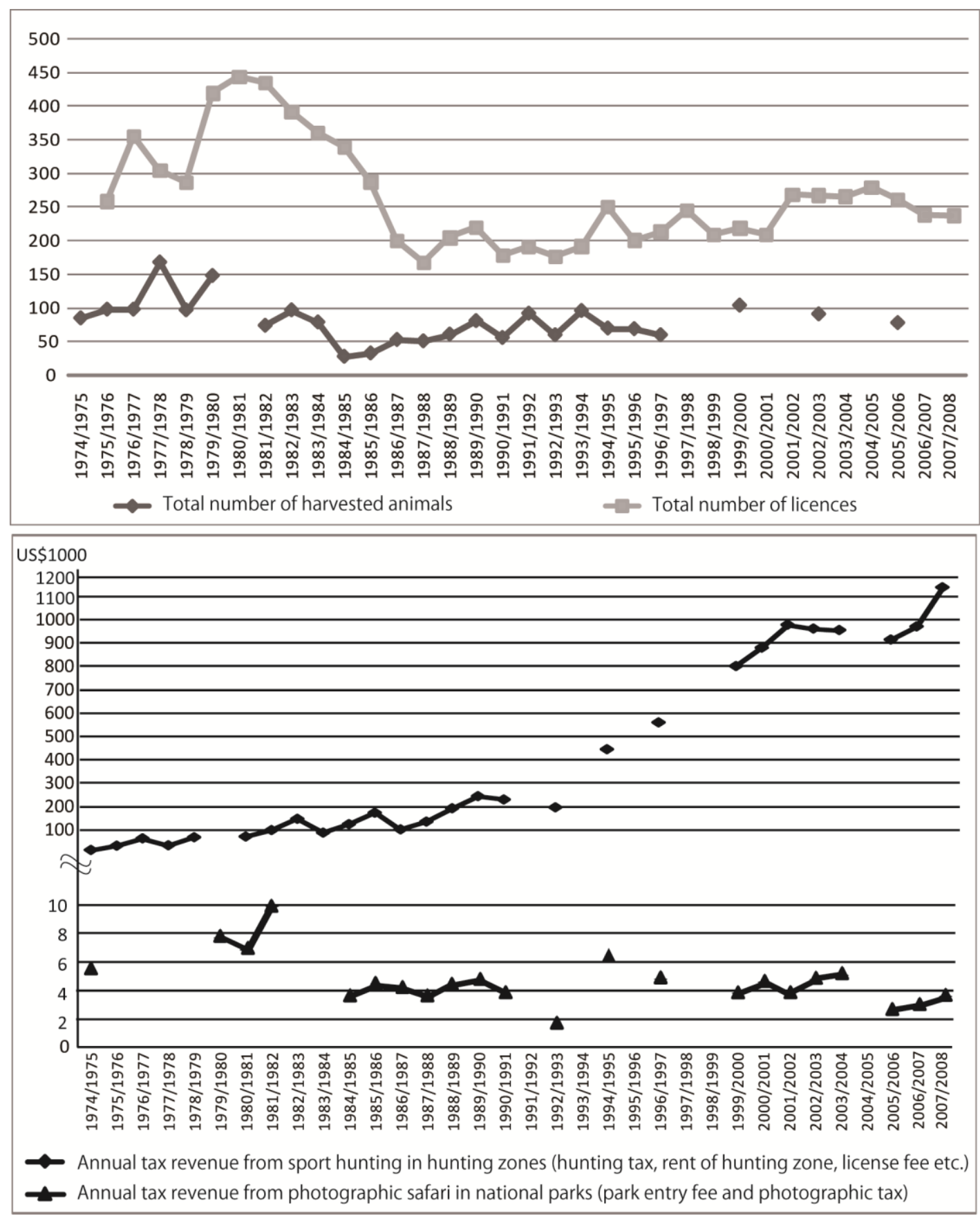

Figure 2. (a) Total number of harvested animals (elephant, buffalo, lion) and hunting licenses and (b) annual tax revenues from sport hunting in hunting zones and photographic safari in national parks in North province, Cameroon, from 1974 to 2007. Source: Re'publique du Cameroun 1985a; 1985b; 1990; 1991; 1993; 1997; 2000; 2003; 2005; 2006; 2007; 2008; 2009; Re'publique Unie du Cameroun 1981; SNV 1996; WWF 2000

Hunting zones have expanded since their establishment in 1968 and, as of 2007 occupied 2.57 
million ha in 31 blocks, i.e. 3.5 times more than in 1968 ( 0.73 million ha in 16 blocks). This may be because the government has emphasized the value of tax revenue from sport hunting, as discussed below. Hunters visiting Cameroon must pay hunting operators for a license and for the animals they hunt. Of this revenue, $70 \%$ goes into the national treasury and 30\% to the Ministry of Wildlife and Forestry. The rent paid for hunting zones is divided with $50 \%$ going to the Ministry, $40 \%$ to the local council, and $10 \%$ to the community commission, which is made up of several villagers who live in the hunting zone. The Ministry regards these tax revenues as a source of funds for conservation activities (MINEF 2002). In 2008, the tax revenue generated from sport hunting, including license fees, trophy fees, and rent of hunting zones, reached about US\$1.2 million, which was about 310 times higher than revenue gained from photographic safari in national parks in North province (about US\$4,500)(Figure 2 (b)).

\section{Impact of Sport Hunting on Local Livelihoods}

In the study village, there are two major effects from sport hunting on the livelihood of the villagers: the generation of employment and profit sharing, and restrictions on rights to use natural resources.

The villagers' livelihood mainly came from farming (corn, sorghum, cotton, and groundnuts), but sport hunting created employment opportunities and a share of the revenue generated from tourism. As of January 2007, 22 men between ages 19 and 57 (40\% of the men between 19 and 60 in the village) were employed by operators in capacities such as trackers (2 villagers) to trace animals and offer advice to hunters, skinners to make trophies (2 villagers), porters (4 villagers), road workers and other odd-jobs men (14 villagers). For those who had an important position, such as tracker or skinner (18\% of the employees), these activities formed a major part of their 
annual income. For example, the interviews in the village in 2007 revealed that one of the skinners earned US $\$ 829$ during the 5 months of the hunting season, which is about $85 \%$ of the annual household income, much more than selling cotton (US\$37; 4\%) or groundnuts (US\$109; $11 \%)$. However, not all employees earn as much money; a road worker earned only US\$68 for one month's work.

As for profit sharing from the rent of hunting zones, which has been carried out since 2000, in 2008, community commissions in North province received a total of US $\$ 29,194$ from the Ministry (République du Cameroun 2009). However, this represented only $2.1 \%$ of the total revenue of sport hunting from that year (US\$1.2 million), which consisted of trophy fees (US\$716,585), rent for hunting zones (US\$291,943), hunting license fees (US\$121,634), professional hunter license fees (US\$40,151), and an arms tax (US\$380) (République du Cameroun 2009). Annual reports of the Ministry show that between 2000 and 2008, 2.6\% of the total revenue from sport hunting in North province was shared with communities.

The study village established the community commission with six other villages. The commission consisted of one president and four members from the village and 17 members from other villages. The members were called "community anti-poaching members" and cooperated with the government and operators' anti-poaching activities. The commission received dividends of US $\$ 1,885$ in 2007 , of which $33 \%$ was spent for the repair or construction of a school, and $64 \%$ was used for the members' salary and purchasing their shoes. Five residents of the study village ( $1 \%$ of all villagers) enjoyed most of the benefits.

Sport hunting had negative effects on villagers by restricting their rights to use natural resources. Each hunting operator who leases a hunting zone obtains the right to use and exploit the natural resources in that zone. On the other hand, the rights of local people to graze, fish, and cut down 
trees in hunting zones were restricted by the hunting operators as well as the ministry. Hunting by local people has also strictly been banned, which causes conflict between hunting operators and local people.

Interviews and observations showed that local people mainly hunted antelopes using handmade guns called ngaoundal, wire traps, and bows and arrows. The diet survey showed that meat appeared on the table at every fourth meal. I accompanied the villagers on hunting five times during the research period. I also conducted informal interviews with reliable informants and was informed that most meat consumed was bush meat they had hunted or bought from other villagers. There are not enough domestic animals in the village to cover this meat-meal frequency. In 2007, according to interviews with all village households $(\mathrm{N}=25)$, each household had on average only 2.3 goats and 5.5 chickens. As a result, it is quite likely that most of the meat served at the table was bush meat, which provides an important source of daily protein for local people.

These hunting activities by local people are considered illegal, because they are carried out inside the zone that requires a hunting license and payment of taxes to hunt animals, and only hunting operators have the right to use the natural resources. I never met a villager who had a hunting license or who would have been able to afford to pay the high tax on one. Even outside the hunting zone, a person who has no hunting license is only permitted to engage in "traditional hunting," or hunting that targets the wildlife belonging to Class $\mathrm{C}$ and using weapons made from materials of plant origin in accordance with Section 86 of the Law. Therefore, hunting with guns or wire traps that local people now practice is considered illegal (MINEF 2002). Thus, whether the hunting occurs inside or outside the zone, the present methods used by local people ensure that the activity is regarded as poaching.

Regular monitoring of poaching has been conducted by Ministry officers and employees of 
hunting operators called "anti-poaching teams." Poachers caught by these teams are arrested and taken to the Ministry, gendarmerie, police, and court. They are fined up to US\$20,000 and/or imprisoned for a year in accordance with the Law. Prison records from a town nearby the study village show that, 362 people were imprisoned during 2008, with about 107 of them (30\%) having been charged with poaching.

The hunting operators and officers claimed that hunting by local people was unsustainable and adversely affected wildlife. One of the hunting operators said to the villagers, "I built a school in this village and have employed you in my camp. However, the length of ivory has been shortening year by year because of poaching. What will you do if children cannot work in the camp?" In addition, an officer stated, "The local people hunt wildlife without paying taxes and considering the sex and age of animals. The hunting they do is not sustainable. That is why their hunting is banned".

However, local people stated that the "white man bought this land" (male, age 21), and they also complained that "we just want to hunt wildlife to eat several times a week" (male, age 43). Under this repressive situation, for example, villagers who are members of an anti-poaching team may actually be poachers (e.g. Weladji and Tchamba 2003), trying to obtain the profits from both sport hunting (such as employment opportunities and profit sharing) and bush meat from poaching for their livelihoods.

\section{Discussion}

This study aimed to introduce the present situation of sport hunting in Northern Cameroon, and to analyze the social and economic impacts of sport hunting on local people. In Northern Cameroon, sport hunting generates employments in camps for local people. In the study village, those who had a position gained some cash income, especially if they held an important position. 
For example, one skinner earned most of his household's annual income. However, such villagers were only $18 \%$ of employees, and all the employees accounted for $40 \%$ of the men between 19 and 60 in the village.

Sport hunting also generated annual tax revenues about US\$1.2 million, far more than photographic safaris in national parks. Local people who live in hunting zones have received profit-sharing income from the Ministry in the form of $10 \%$ of the rent of hunting zones. However, this amount was only $2.6 \%$ of the total tax revenue from sport hunting between 2000 and 2008; other non-rent income, such as trophy and license fees, is distributed only between the national treasury and the Ministry.

In contrast, the ADMADE (Administrative Management Design) program in Zambia receives half of the trophy fees and all of the license fees, and uses $47 \%$ of them for community development in Game Management Areas (Lewis and Alpert 1997). Consequently, local communities receive $12 \%$ of hunting revenues (Lindsey et al. 2007).

Compared to other nations such as Zambia (12\%) and Tanzania (25\%) (Lindsey et al. 2007), the proportion of hunting revenue distributed to local people in Northern Cameroon seems low. Furthermore, the majority of the money distributed to the community commission was used by a small proportion of the villagers who cooperated with anti-poaching activities. To improve inequitable distribution of wildlife benefits and costs, the portion of revenue that is distributed to communities could be raised (e.g. Mayaka 2002) and divided fairly among each household, as it is in the CAMPFIRE project in Zimbabwe (Frost and Bond 2008).

Sport hunting has caused restrictions on local people's rights to use natural resources. In the study village, although the villagers depend on bush meat as their daily protein source, their hunting of wildlife was permitted only as "traditional hunting." The present hunting they carry 
out with guns and wire traps is regarded as poaching and unsustainable by the Ministry and hunting operators.

As for sustainability, some conservationists argue that sport hunting can be practiced sustainably as a form of controlled hunting (Bond et al. 2004; Lindsey et al. 2007). Unlike sport hunting by Westerners, hunting by local people seems to be historically regarded as unsustainable by authorities. During the colonial period, Western hunters regarded their own activity as noble and thrifty sport hunting (Neumann 1998), as opposed to the hunting of local people who engaged "without mercy and discrimination," (Bryden 1905, p. 16). Despite Westerners' excessive hunting with modern weapons, they insisted that the extermination of African game was caused by Africans (Bryden 1905; Ritvo 1987). The differentiation between sport hunting and hunting by local people has continued through the use of the terms of sustainable or unsustainable, as a Cameroonian officer stated. The idea of sustainability has been interpreted by authorities in (neo) colonial and political statements and from economic viewpoints in an attempt to use historical power structures to condemn local hunting and legitimize sport hunting.

There is a lively discussion on the ecological sustainability of local hunting by many ecologists and anthropologists. As Adams and Hutton (2007) indicated, debates about the social impacts of conservation and tourism on local people around protected areas are of obvious importance, as is the exclusiveness of the social and political contexts in the framing of ecological and financial sustainability. To develop well-managed community conservation policies that sport hunting, conservation, and local livelihoods to coexist, social impacts and historical relationships between local people and sport hunting should be addressed. 


\section{References}

Adams, W. and D. Hulme. 2001. Conservation \& community: Changing narratives, politics \& practices in Africa conservation. In African wildlife \& livelihoods: The promise and performance of community conservation, ed. D. Hulme and M. Murphree. Pp. 9-23. Oxford, UK: James Currey.

Adams, W. and J. Hutton. 2007. People, parks and poverty: Political ecology and biodiversity conservation. Conservation and Society 5 (2): 147-183.

Baker, J. E. 1997. Trophy hunting as a sustainable use of wildlife resources in southern and eastern Africa. Journal of Sustainable Tourism 5 (4): 306-321.

Bond, I., B. Child, D. de la Harpe, B. Jones, J. Barnes, and H. Anderson. 2004. Private land contribution to conservation in South Africa. In Parks in transition, ed. B. Child. Pp. 29-61. London, UK: Earthscan.

Bryden, H. A. 1905. Introductory. In Big game shooting Vol.2, ed. Horace G. Hutchinson. Pp. 3-18. London: Country Life.

Cernea, M. M. 2006. Population displacement inside protected areas: A redefinition of concepts in conservation politics. Policy Matters 14:8-26.

Chambers, R. 1994. The origins and practice of participatory rural appraisal. World Development 22(7): 953-969.

Chapin, M. 2004. A challenge to conservationists. World Watch 17(6): 17-31.

Chardonnet, P., B. des Clers, J. Fischer, R. Gerhold, F. Jori, and F. Lamarque. 2002. The value of wildlife. Revue Scientifique et Technique 21(1): 15-51.

Fairhead, J. and M. Leach. 2000. The nature lords. Times Literary Supplement 5 May 2000 pp. 
Yasuda, A.

3-4.

Frost, P. G. H. and I. Bond. 2008. The CAMPFIRE programme in Zimbabwe: Payment for wildlife services. Ecological Economics 65:776-787.

Lewis, D. M. and P. Alpert. 1997. Trophy hunting and wildlife conservation in Zambia. Conservation Biology 11(1): 59-68.

Lindsey, P. A., P. A. Roulet, and S. S. Romanache. 2007. Economic and conservation significance of trophy hunting industry in sub-Saharan Africa. Biological Conservation 134:455-469.

Mayaka, T. B. 2002. Wildlife co-management in the Bénoué National Park -Complex, Cameroon: A bumpy road to institutional development. World Development 30 (11): 2001-2016.

MINEF (Ministère de 1'Environnement et des Forêts) . 2002. Plan d'amenagement et de gestion du parc et de sa zone peripherique (Plan of modificationa and management of park and peripheral zone) 2002-2006. Garoua, Cameroon: MINEF.

Neumann, R. P. 1998. Imposing wilderness: Struggles over livelihood and nature preservation in Africa. Berkeley, CA: University of California.

Ritvo, H. 1987. The animal estate: The English and other creatures in the Victorian Age. Cambridge, MA: Harvard University Press.

Roulet, P. A. 2004. Chasse sportive et gestion communautaire de la faune sauvage en Afrique central (Sport hunting and community management of wildlife in Central Africa). Game and Wildlife Science 21(4): 615-632.

République du Cameroun. Délégation Générale au Tourisme. 1985a. Tourisme cynégétique dans le Nord-Cameroun (Hunting tourism in Northern Cameroon) 1974-1984. Garoua, Cameroon: 
Délégation Générale au Tourism.

République du Cameroun. Délégation Générale au Tourisme. 1985b. Rapport annuel délégation provinciale du Nord, de l'extrême-Nord et de l'Adamaoua période du $1^{\text {er }}$ juillet 1984 au 30 juin 1985 (Annual report provincial delegation of North, Extreme North, and Adamawa period from July 1st 1984 and June 30th 1985). Garoua, Cameroon: Délégation Générale au Tourisme.

République du Cameroun. Ministère du Tourisme. 1990. Rapport annuel délégation provinciale du tourism pour Nord période du $1^{\text {er }}$ juillet 1989 au 30 juin 1990 (Annual report provincial delegation of tourism for North province period from July 1 st 1989 and June 30th 1990). Garoua, Cameroon: Ministère du Tourisme.

République du Cameroun. Ministère du Tourisme. 1991. Rapport annuel d'activités (Annual activity report) 1990-1991. Garoua, Cameroon: Ministère du Tourisme.

République du Cameroun. Ministère du Tourisme. 1993. Rapport annuel d'activités (Annual activity report) 1992-1993. Garoua, Cameroon: Ministère du Tourisme.

République du Cameroun. Ministère de l'Environnement et des Forêts. 1997. Rapport annuel délégation provinciale de l'Environnement et des Forêts du Nord (Annual report of provincial delegation of environment and forest, North province) 1996-1997. Garoua, Cameroon: Ministère de l'Environnement et des Forêts.

République du Cameroun. Ministère de l'Environnement et des Forêts. 2000. Rapport annuel délégation provinciale de l'Environnement et des Forêts du Nord (Annual report of provincial delegation of environment and forest, North province). Garoua, Cameroon: Ministère de l'Environnement et des Forêts.

République du Cameroun. Ministère de l'Environnement et des Forêts. 2003. Rapport d'activité 
annuel de la délégation provinciale du Nord année 2003 (Annual activity report of provincial delegation, North province 2003). Garoua, Cameroon: Ministère de l'Environnement et des Forêts.

République du Cameroun. Ministère des Forêts et de la Faune. 2005. Rapport annuel de la délégation provinciale des Forêts et de la Faune du Nord (Annual report of provincial delegation of forest and wildlife, North province). Garoua, Cameroon: Ministère des Forêts et de la Faune.

République du Cameroun. Ministère des Forêts et de la Faune. 2006. Rapport annuel de la délégation provinciale des Forêts et de la Faune du Nord (Annual report of provincial delegation of forest and wildlife, North province). Garoua, Cameroon: Ministère des Forêts et de la Faune.

République du Cameroun. Ministère des Forêts et de la Faune. 2007. Rapport annuel de la délégation provinciale des Forêts et de la Faune du Nord (Annual report of provincial delegation of forest and wildlife, North province). Garoua, Cameroon: Ministère des Forêts et de la Faune.

République du Cameroun. Ministère des Forêts et de la Faune. 2008. Rapport annuel de la délégation provinciale des Forêts et de la Faune du Nord (Annual report of provincial delegation of forest and wildlife, North province). Garoua, Cameroon: Ministère des Forêts et de la Faune.

République du Cameroun. Ministère des Forêts et de la Faune. 2009. Rapport annuel de la délégation provinciale des Forêts et de la Faune du Nord (Annual report of provincial delegation of forest and wildlife, North province). Garoua, Cameroon: Ministère des Forêts et de la Faune. 
Society and Natural Resources 24 (8): 860-869.

République Unie du Cameroun. Délégation Générale au Tourisme. 1981. Rapport annuel exercice 1980-1981(Annual report exercise 1980-1981). Garoua, Cameroon: Délégation Générale au Tourisme.

SNV (Netherlands Development Organisation). SNV-Cameroun. 1996. Gestion participative des aires protégées dans la province du Nord Cameroun (Participative management of protected areas in North province, Cameroon). Cameroon: SNV-Cameroun.

Weladji, R. B. and M. N. Tchamba. 2003. Conflict between people and protested areas within the Bénoué Wildlife Conservation Area, North Cameroon. Oryx 37(1): 72-79.

Wilkie, D. S. and J. F. Carpenter. 1999. The potential role of safari hunting as a source of revenue for protected areas in the Congo Basin. Oryx 33(4): 339-345.

WWF (World Wildlife Federation). WWF-Cameroun. 2000. Les activités cynégétiques dans la province du Nord Cameroun entre 1983 et 1997(The hunting activity in North Province, Cameroon between 1983and 1997). Garoua, Cameroon: WWF-Cameroun.

WWF. WWF-Cameroun. 2007. Taille, Structure, Distribution et Biomasse des Grands et Moyens Mammifères Diurnes dans le Parc National de la Bénoué et les ZIC 1 \&4 (Size, distribution, and biomass of large and medium diurnal Mammalia in Bénoué national park and ZIC 1 \& 4). Garoua, Cameroon: WWF-Cameroun. 